\title{
Retraction
}

\section{Retracted: A Design of Dual Broadband Antenna in Mobile Communication System}

\section{International Journal of Antennas and Propagation}

Received 15 November 2016; Accepted 15 November 2016

Copyright ( 2016 International Journal of Antennas and Propagation. This is an open access article distributed under the Creative Commons Attribution License, which permits unrestricted use, distribution, and reproduction in any medium, provided the original work is properly cited.

International Journal of Antennas and Propagation has retracted the article titled "A Design of Dual Broadband Antenna in Mobile Communication System" [1]. The article was found to contain a substantial amount of material, without citation, from the following published article: Y. Cui, R. Li and P. Wang, "Novel Dual-Broadband Planar Antenna and Its Array for 2G/3G/LTE Base Stations," in IEEE Transactions on Antennas and Propagation, vol. 61, no. 3, pp. 1132-1139, March 2013. doi: 10.1109/TAP.2012.2229377, where Figures 1, 3, 4, 5, 7 and 9 and Table 1 were reused in Figures 1, 2, 7, 6, 8 and 5 and Table 1 in this article.

\section{References}

[1] J. Zhou, "A design of dual broadband antenna in mobile communication system," International Journal of Antennas and Propagation, vol. 2015, Article ID 975825, 9 pages, 2015 